\title{
Symptomatology, isolation, identification and pathogenicity test of damping off disease in okra
}

\author{
S.R. JUKTE, S.L. BADGUJAR*, A.P. SURYAWANSHI, UTPAL DEY AND D.P. KULDHAR \\ Department of Plant Pathology, V.N. Marathwada Krishi Vidyapeeth, PARBHANI (M.S.) INDIA
}

\section{ARITCLE INFO}

Received : 12.09 .2013

Accepted : 27.03.2016

\section{KEY WORDS :}

Damping off, Isolation, Okra, Pythium spp., Pathogenicity, Symptomatology

*Corresponding author:

Email: sandeepbadgujar@ rediffmail.com

\begin{abstract}
Damping off diseases in okra is an economically most important and destructive disease of okra. The main characteristic symptom of the disease is pre- emergence damping off i.e. rotting of the seeds and seedlings before actual emergence from the soil and postemergence damping off which is severe when the seedlings are in cotyledonous stage. The infected tissues become soft and water soaked resulting in toppling over of the entire plant on the soil surface. The test pathogen (Pythium aphanidermatum) was isolated successfully on the basal culture medium Potato dextrose agar, from the seedlings showing typical symptoms of damping off. The pathogen produced nonseptate, well branched, colourless to white mycelium, lobed sporangia on indeterminate sporangiophores, and formation of resting spore (oospore) when observed under the microscope. Pathogenicity of $P$. aphanidermatum was proved by sick soil method in pot culture, sowing okra cv. PARBHANI KRANTI under screen house condition and by water agar method. The pathogen was reisolated on PDA from artificially diseased okra seedling, and compared its cultural and morphological characteristics with the original fungus isolated from the naturally damping off diseased okra plant.
\end{abstract}

How to view point the article : Jukte, S.R., Badgujar, S.L., Suryawanshi, A.P., Dey , Utpal and Kuldhar, D.P. (2016). Symptomatology, isolation, identification and pathogenicity test of damping off disease in okra. Internat. J. Plant Protec., 9(1) : 358-361. 